\title{
OPEN Characterization and phylogeny of fungi isolated from industrial wastewater using multiple genes
}

\author{
Blessing Amaka Ezeonuegbu ${ }^{1 凶}$, Machido Dauda Abdullahi ${ }^{1}$, Clement M. Z. Whong ${ }^{1}$, \\ Japhet Wisdom Sohunago ${ }^{2}$, Hazem S. Kassem ${ }^{3}$, Clement Ameh Yaro $\mathbb{1}^{4}$, Helal F. Hetta ${ }^{5,6}$, \\ Gomaa Mostafa-Hedeab ${ }^{7}$, George D. Zouganelis ${ }^{8,9 \square}$ \& Gaber El-Saber Batiha ${ }^{10}$
}

The aim of this study was the isolation and molecular characterization of fungi from untreated refinery effluent by using multiple conserved genes. The Fungi isolated were characterized based on PCR amplification and genomic sequencing of the internal transcribed spacer region (ITS), partial $\beta$-tubulin (BenA), calmodulin (CaM), and RNA polymerase second large subunit (RPB2) genes, along with morphological characterization. The obtained sequences were subjected to BLAST analysis and the corresponding fungal isolates were assigned species names after comparison with representative sequences available in GenBank. Fifteen (15) Fungi species belonging to four genera of Aspergillus, Penicillium, Fusarium, and Trichoderma with Aspergillus as the predominant genus were identified. Therefore these genes should be used as molecular markers for species level identification of fungi (especially Aspergillus and Penicillium as proven in this study.

Wastewater from various industries are composed of organic and inorganic complex pollutants including heavy metals, xenobiotics, polyaromatic hydrocarbons (PAHs), strong acids and suspended materials which cause major environmental pollution worldwide ${ }^{1,2}$. The microorganisms present in wastewater are archaea, bacteria, fungi, algae, protozoa and viruses ${ }^{3,4}$. The abundance and diversity of these organisms are influenced by parameters like temperature, $\mathrm{pH}$, salinity and dissolved oxygen ${ }^{1}$. A great number of molecular studies have investigated archaea and bacterial diversity of various wastewater ${ }^{5,6}$, but fewer have addressed fungi ${ }^{1}$.

Fungi are diverse group of eukaryotic organisms characterized as heterotrophic, saprophytic, symbiotic and parasitic due to their achlorophyllous nature. Their cell walls are made up of $\beta$-glucans and chitin ${ }^{7}$. They are known as the second largest after kingdom Animalia with estimate of over 5 million species ${ }^{8}$. Fungi have the ability to metabolically utilize various substrates such as carbohydrates, proteins, lipids, aromatic hydrocarbons, and other chemical compounds as sole sources of carbon ${ }^{6,13}$. They perform several functions in wastewater systems harboring them, which include detoxification, biodegradation and decolourization of pollutants ${ }^{1,9}$.

Apart from known enormous importance of fungi, the taxonomy of these organisms is still challenging due to a lack of reliable and advanced techniques for their identification and systematic studies. Earlier studies on the composition of fungi in wastewater were either dependent on traditional method of identification based on growth, morphology, metabolism and enzymatic activity ${ }^{1,10}$, or the use of one molecular marker gene to identify the fungi to specie levels ${ }^{11,12}$. However, the use of multiple marker genes for identification of fungal communities in wastewater has not been extensively studied. In order to resolve the difficulties of fungal identification to species level, several genetic markers for rapid classification of fungi having conserved sequences, include internal transcribed spacer regions (ITS), Beta-tubulin genes (Ben A), Calmodulin (CaM) and RNA polymerase II gene $(\mathrm{RPB} 2)^{8,13-15}$.

\footnotetext{
${ }^{1}$ Department of Microbiology, Ahmadu Bello University, Zaria, Nigeria. ${ }^{2}$ Department of Botany, Ahmadu Bello University, Zaria, Nigeria. ${ }^{3}$ Department of Agricultural Extension and Rural Society, College of Food and Agriculture Sciences, King Saud University, Riyadh 11451, Saudi Arabia. ${ }^{4}$ Department of Animal and Environmental Biology, University of Uyo, Uyo, Akwa Ibom State, Nigeria. ${ }^{5}$ Department of Medical Microbiology and Immunology, Faculty of Medicine, Assiut University, Assiut 71515, Egypt. ${ }^{6}$ Department of Internal Medicine, University of Cincinnati College of Medicine, Cincinnati, OH 45267-0595, USA. ${ }^{7}$ Pharmacology Department, Faculty of Medicine, Beni-Suef University, Beni Suef, Egypt. ${ }^{8}$ Human Sciences Research Centre, University of Derby, Derby DE22 1GB, UK. ${ }^{9}$ Novel Global Community Educational Foundation, Hebersham, NSW 2770, Australia. ${ }^{10}$ Department of Pharmacology and Therapeutics, Faculty of Veterinary Medicine, Damanhour University, Damanhour 22511, AlBeheira, Egypt. ${ }^{\boxplus}$ email: amakaezeonu@gmail.com; G.Zouganelis@derby.ac.uk
} 
The internal transcribed spacer regions (ITS) are used as official universal DNA barcode for fungi ${ }^{14,15}$. The ITS1, ITS2, and ITS4 have been proven to be useful for the identification of yeasts and some fungi such Aspergillus, Penicillium, Talaromyces, Cryptococcus, candida, and Trichosporon species among many others ${ }^{14-16}$. However, ITS sequences cannot be used for phylogenetic analyses of unrelated taxa due to low variability and slow evolution. Also, ITS sequences do not always allow correct species differentiation especially among Aspergillus and Penicillium genera ${ }^{17,18}$. Hence, additional gene markers are essential for correct species delineation. Secondary molecular markers such as beta tubulin; calmodulin and RPB2 have been successfully used in fungal genomics ${ }^{8,15,18}$. Reports have shown that these protein-encoding genes contained highly variable intron regions which contain highly variable introns that evolve at a faster rate compared to ITS ${ }^{18,19}$.

Beta-tubulin genes are found in all eukaryotes encoding for polypeptide proteins. They have been used for phylogenetic analysis in fungi from the entire kingdom to the species level. Four Beta tubulin genes are found in all fungi; two $\alpha$-tubulin (tub A) and two $\beta$-tubulin (tub B) genes. Tub A is responsible for the production of two alpha tubulin polypeptides (alpha 1 and alpha 2) while Tub B produces one alpha polypeptide (alpha $2)^{13}$. Reports have it that beta-tubulin gene sequences contain 3.5-fold more phylogenetic information than the small sub-unit (SSU) rRNA gene, thus it has been reported that it is an ideal marker for analysis of deep-level phylogenies and for complex species groups ${ }^{8,18}$.

Calmodulin $(\mathrm{CaM})$ is a small acidic protein present in all eukaryotic cells and shown to be highly conserved both functionally and structurally $\mathrm{y}^{20,21}$. Its primary role is to serve as an intracellular $\mathrm{Ca}^{2+}$ receptor which signal proliferation, motility, and cell cyclic progression. $\mathrm{Ca}^{2+}-\mathrm{CaM}$ complexes act by controlling the activity of numerous intracellular proteins such as phosphodiesterase, $\mathrm{Ca}^{2+}$-ATPase, serine protein kinases, and protein phosphatases. It also acts on several metabolic pathways and gene expression regulation in many eukaryotic organisms including fungi ${ }^{20}$.

RNA polymerase II gene (RPB2) encodes for second largest protein subunit in eukaryotes which synthesizes mRNA precursors and functional non-coding RNAs ${ }^{22,23}$. A study ${ }^{24}$ reported that RPB2 gene is a viable alternative molecular marker for the analysis of environmental fungal communities due its discriminative power, quantitative representation of community composition and suitability for phylogenetic analyses. Therefore this study was aimed at isolation and molecular identification of indigenous fungi from untreated refinery wastewater using multiple genes.

\section{Materials and methods}

Collection of untreated refinery effluents. Samples of untreated effluent were collected from waste water channel of Kaduna Refinery and Petrochemical Company (KRPC), Kaduna State, Nigeria. The samples were collected in sterile sample bottles. The bodies of the bottles were rinsed thoroughly with sterile distilled water before transporting them in ice box to the laboratory for fungal isolation ${ }^{25}$.

Isolation and molecular characterization of test fungi from untreated refinery effluent. Isolation of fungi from untreated waste water. The effluent samples were removed from the ice box and kept to stand on a sterile laboratory work bench. $10 \mathrm{ml}$ of the samples in duplicates were aseptically dispensed in sterile centrifuge tubes and centrifuged at a speed of $250 \mathrm{rpm}$ for $10 \mathrm{~min}$ to concentrate the samples. A portion $(0.1 \mathrm{ml})$ of the residue of each sample was spread-plated on sterile potato dextrose agar (PDA) (Oxoid ltd, Basinstoke, United Kingdom) and Malt Extract Agar (MEA) (Oxoid ltd, Basinstoke, United Kingdom) plates in duplicate (containing $50 \mu \mathrm{g} / \mathrm{L}$ of chloramphenicol), using sterile bent glass rod. The plates were incubated at room temperature $\left(30^{\circ} \mathrm{C}\right)$ for 7 days $^{26}$.

Colony morphology and microscopic characterization of fungal Isolates. Colonies grown on each medium were distinguished on the basis of their surface characteristics such as texture, colour, zonation, sporulation and diameters ${ }^{25}$. The distinguishable colonies were sub-cultured on PDA slant and incubated at room temperature $\left(30^{\circ} \mathrm{C}\right)$ for 7 days to obtain pure isolates. The microscopic characteristics were carried out by mounting small portion of the growing region of the fungi on a clean grease free slide with a drop of lacto phenol cotton blue, covered with a cover slip and examined under electron microscope using $\times 40$ objective lens. The isolates were characterized and identified using taxonomic guide ${ }^{19,27,28}$. The pure isolates were maintained in PDA slants and stored in refrigerator for further identification.

Molecular identification of fungal isolates. Extraction of fungal genomic DNA. Each of the isolates was grown on potato dextrose agar at room temperature for 5 days. This was followed by sub-culturing each isolates into a $250 \mathrm{~mL}$ Erlenmeyer flask containing $100 \mathrm{~mL}$ potato dextrose broth (Oxoid ltd, Basinstoke, United Kingdom) and incubated for 5 days. The mycelial mass produced by each isolate was separated from the broth by filtration through sterile No. 5 Whatman filter paper. The mycelial mass was crushed using porcelain mortar and transferred to Eppendorf tubes for extraction.

The genomic DNA extraction was carried out using ZR Fungal/Bacterial DNA MiniPrep Kit (Zymo Research, Irvine, CA, USA) according to manufacturer's manual instructions ${ }^{14,16,29,30}$.

PCR amplification of the target genes. Primers specific for internal transcribed spacer region (ITS), betatubulin gene (benA), calmodulin gene (CaM) and RNA polymerase II second largest subunit (RPB2) loci are presented in Table 1.

PCR amplification of the extracted DNA was performed in a $20 \mu \mathrm{L}$ reaction mixture as follow: $1 \mu \mathrm{L}$ gDNA template, $0.2 \mu \mathrm{L}$ DNA polymerase, $0.5 \mu \mathrm{L}$ each forward and reverse primers, $1 \mu \mathrm{L}$ dNTPs and sterile double distilled water to a final volume of $20 \mu \mathrm{L}$. The thermocycler was programed for the following PCR conditions: 


\begin{tabular}{|c|c|c|c|c|c|}
\hline Locus & Primer & Direction & Oligonucleotide sequence $\left(5^{\prime}-3^{\prime}\right)$ & Length (bp) & References \\
\hline \multirow{2}{*}{ Internal Transcribed Spacer (ITS) } & ITS1 & Forward & TCC GTA GGT GAA CCT GCG G & \multirow{2}{*}{600} & \multirow{2}{*}{14,17} \\
\hline & ITS4 & Reverse & TCC TCC GCT TAT TGA TAT GC & & \\
\hline \multirow{2}{*}{$\beta$-tubulin (BenA) } & Bt2a & Forward & $\begin{array}{l}\text { GGT AAC CAA ATC GGT GCT GCT } \\
\text { TTC }\end{array}$ & \multirow{2}{*}{550} & \multirow{2}{*}{$14,17,31$} \\
\hline & Bt2b & Reverse & $\begin{array}{l}\text { ACC CTC AGT GTA GTG ACC CTT } \\
\text { GGC }\end{array}$ & & \\
\hline \multirow{2}{*}{ Calmodulin (CaM) } & CMD5 & Forward & CCG AGT ACA AGG ARG CCT TC & \multirow{2}{*}{580} & \multirow{2}{*}{14,17} \\
\hline & CMD6 & Reverse & CCG ATR GAG GTC ATR ACG TGG & & \\
\hline \multirow{2}{*}{$\begin{array}{l}\text { RNA polymerase II second largestsubunit } \\
\text { (RPB2-1) }\end{array}$} & $5 \mathrm{~F}$ & Forward & GAY GAY MGW GAT CAY TTY GG & \multirow{2}{*}{700} & \multirow{2}{*}{$14,17,31$} \\
\hline & 7CR & Reverse & CCC ATR GCT TGY TTR CCC AT & & \\
\hline
\end{tabular}

Table 1. Primers used for the amplification of specific genes in the fungal isolates.

\begin{tabular}{|l|l|l|l|l|l|l|}
\hline Isolate code & Colour & $\begin{array}{l}\text { Surface } \\
\text { characteristics }\end{array}$ & Edge & Reverse colour & $\begin{array}{l}\text { Colony diameter } \\
\text { mm } \text { (mean } \pm \text { SD) }\end{array}$ & $\begin{array}{l}\text { Identity of } \\
\text { isolates }\end{array}$ \\
\hline F1 & Mint green & Powdery & White, circular & Cream & $2.70 \pm 0.00$ & Aspergillus flavus \\
\hline F2 & Black & Granular & White, irregular & Cream & $2.50 \pm 1.02$ & Aspergillus japonicus \\
\hline F3 & Brownish-black & Black & grey, irregular & Black & $2.70 \pm 0.14$ & Aspergillus niger \\
\hline F5 & Black & Granular & Black, irregular & Cream & $1.90 \pm 1.02$ & Aspergillus niger \\
\hline F6 & Pale pink & Granular & light pink, irregular & White & $2.35 \pm 0.07$ & Aspergillus melleus \\
\hline F7 & Dark-green & Cottony & White, irregular & White & $1.35 \pm 0.14$ & Aspergillus sydowii \\
\hline F8 & White & Smooth & White, circular & Cream & $1.20 \pm 0.28$ & $\begin{array}{l}\text { Fusarium incar- } \\
\text { natum }\end{array}$ \\
\hline F10 & Black & Granular & White, irregular & Cream & $2.80 \pm 0.97$ & Aspergillus niger \\
\hline F12 & Whitish gray & Smooth & White, circular & Cream & $0.90 \pm 0.00$ & Penicillium shearii \\
\hline F13 & Whitish-green & Granular & circular & White & $8.00 \pm 0.00$ & $\begin{array}{l}\text { Trichoderma } \\
\text { erinaceum }\end{array}$ \\
\hline F14 & White & Smooth & White irregular & Cream & $1.80 \pm 0.00$ & $\begin{array}{l}\text { Aspergillus quadri- } \\
\text { lineatus }\end{array}$ \\
\hline F16 & Greenish blue & Smooth & White, circular & White & $1.15 \pm 0.07$ & $\begin{array}{l}\text { Aspergillus fumiga- } \\
\text { tus }\end{array}$ \\
\hline F18 & White & Cottony & White, irregular & Cream & $1.85 \pm 0.07$ & Aspergillus sydowii \\
\hline F19 & Bluish-green & Cottony & White, irregular & White & $1.30 \pm 0.00$ & Penicillium citrinum \\
\hline F23 & Dark green & Cottony & White, irregular & White & $1.25 \pm 0.07$ & $\begin{array}{l}\text { Penicillium simpli- } \\
\text { cissimum }\end{array}$ \\
\hline
\end{tabular}

Table 2. Cultural characteristics of fungal isolates from untreated refinery effluent.

initial denaturation at $94^{\circ} \mathrm{C}$ for $5 \mathrm{~min}, 35$ cycles of denaturation at $94^{\circ} \mathrm{C}$ for $45 \mathrm{~s}$, annealing at $55^{\circ} \mathrm{C}$ for $45 \mathrm{~s}$, and extension at $72^{\circ} \mathrm{C}$ for $1 \mathrm{~min}$, with a final extension at $72^{\circ} \mathrm{C}$ for $10 \mathrm{~min}$. For the amplification of RPB2 gene region, touch-up PCR conditions of 5 cycles with annealing temperature $48^{\circ} \mathrm{C}$ followed by 5 cycles at $50{ }^{\circ} \mathrm{C}$ and final 25 cycles at $52^{\circ} \mathrm{C}$ were used. After complete amplification, the PCR products were analyzed for gel electrophoresis by using $1 \%$ agarose gel ( $1 \mathrm{~g}$ of agarose in $100 \mathrm{ml}$ of Tris buffer) with ethidium bromide as the staining agent $\mathrm{t}^{31}$.

Sequencing and phylogenetic analysis. The fungal isolates were identified by DNA sequencing according to standard protocols. Sequencing was carried out in a $28 \mu \mathrm{l}$ reaction mixture as follows: $4 \mu \mathrm{l}$ of each primer, $8 \mu \mathrm{l}$ of purified DNA and $16 \mu \mathrm{l}$ of PCR water and the samples was sequenced with the Di- Deoxy Terminator sequencer. The contigs (formed from forward and reverse sequences) obtained were analyzed using BioEdit 7.2.5 software and aligned using Clustal W of MEGA 7.0 software $^{14,32,33}$. The fungal isolates were assigned species names after comparison with representative sequences available in NCBI (National Center for Biotechnology Information). The obtained sequences were deposited in GenBank and accession number assigned.

The evolutionary history of the fungi was analyzed using the Maximum Likelihood (ML) method based on the Tamura-Nei model of MEGA $7^{33,34}$. The bootstrap tree formed from 1000 replicates represents the evolutionary history of the taxa analyzed. The percentage taxa clustered together in the bootstrap test (1000 replicates) are shown next to the branches ${ }^{31}$.

Results and discussions

Cultural and microscopic characteristics of fungal isolates. Fifteen (15) fungal isolates consisting of four genera; Aspergillus, Penicillium, Fusarium, and Trichoderma were obtained in this study with Aspergillus as the predominant genus (Table 2).The results in Table 2 also revealed the cultural features of the isolates (F1 
a

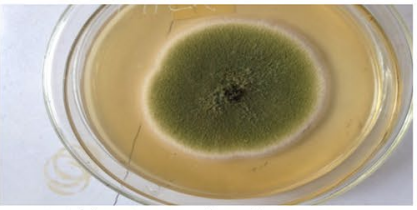

F1(a): Aspergillus flavus

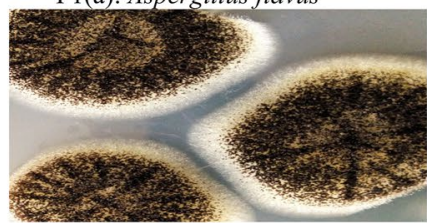

F3(a): Aspergillus niger

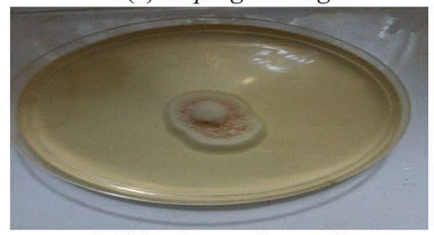

F6(a): Aspergillus melleus

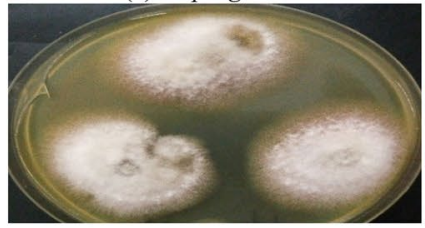

F8(a): Fusarium incarnatum

年

F6(b): Aspergillus melleus
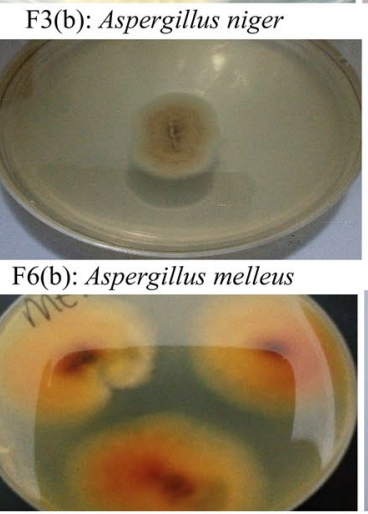

F8(b): Fusarium incarnatum

F1(b): Aspergillus flavus
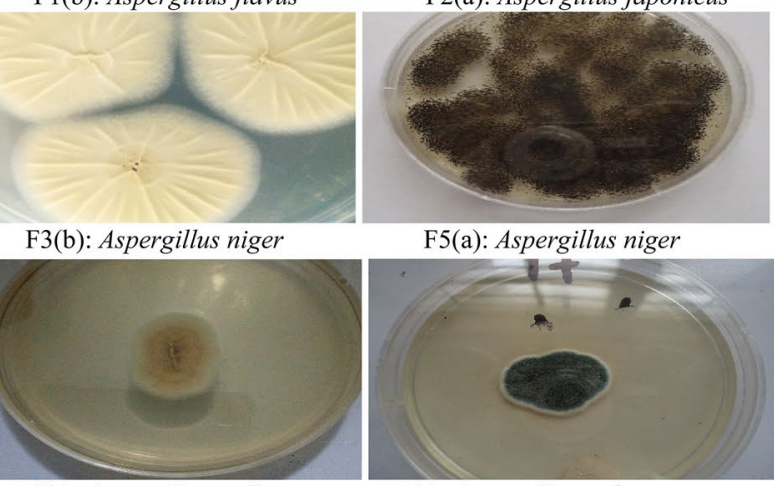

F7(a): Aspergillus sydowii

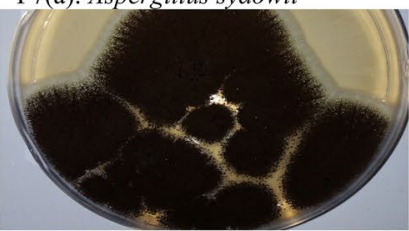

F10 (a): Aspergillus niger

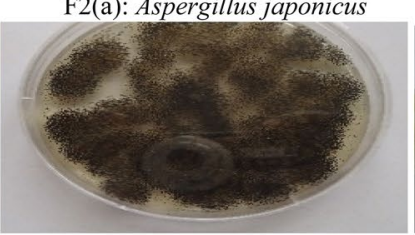

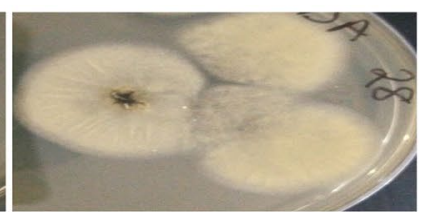

F2(b): Aspergillus japonicus

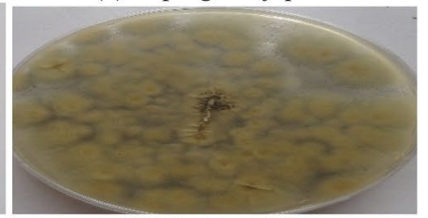

F5(b): Aspergillus niger

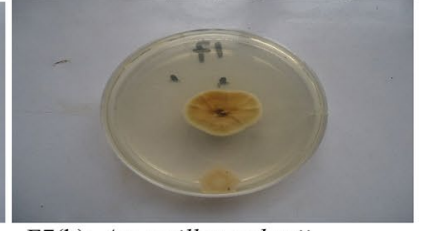

F7(b): Aspergillus sydowii

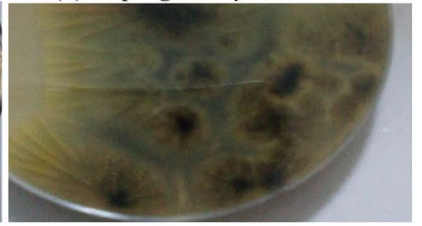

F10(b): Aspergillus niger

b

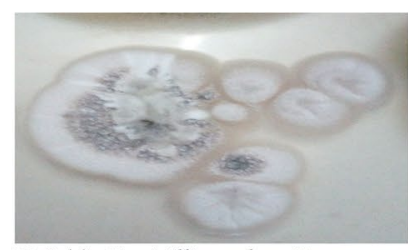

F12 (a): Penicillium shearii

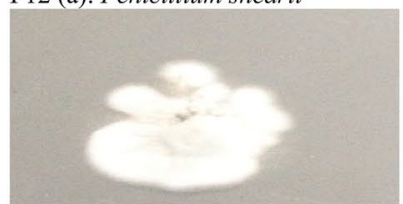

F14 (a): Aspergillus quadrilineatus

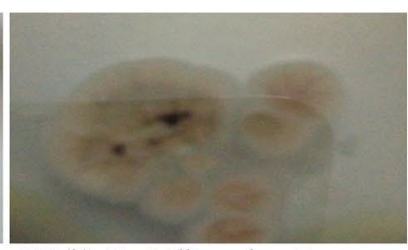

F12(b): Penicillium shearii

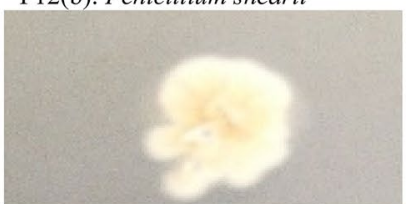

F14 (b): A. quadrilineatus

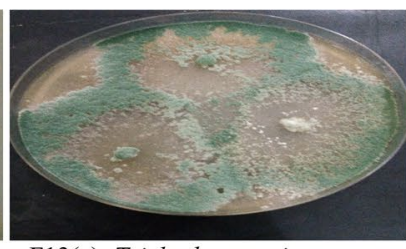

F13(a): Trichoderma erinaceum

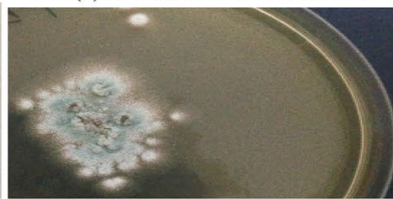

F16 (a): Aspergillus fumigatus

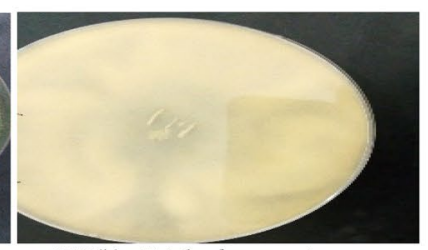

F13(b): Trichoderma erinaceum

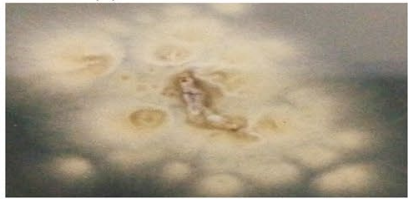

F16 (b): Aspergillus fumigatus

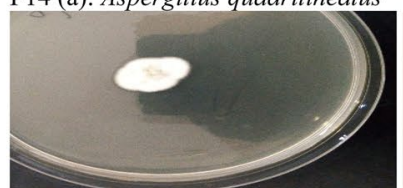

F18 (a): Aspergillus sydowii

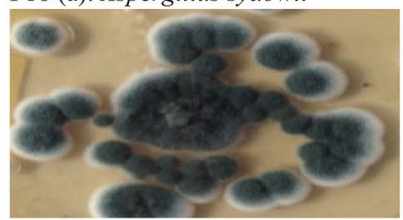

F23 (a): P. simplicissimum

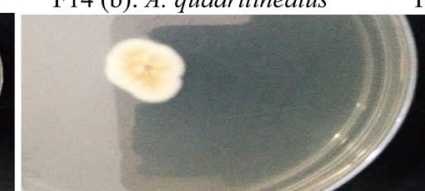

F18 (b): Aspergillus sydowii

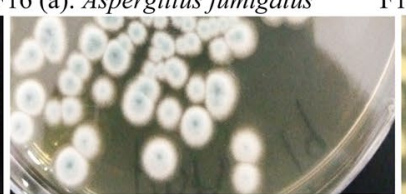

F19 (a): Penicillium citrinum

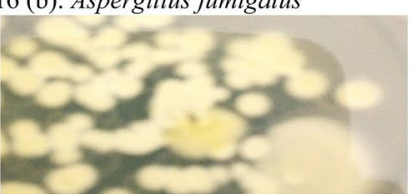

F19 (b): Penicillium citrinum

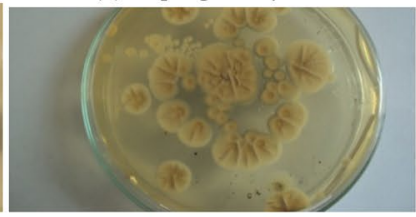

F23 (b): P. simplicissimum

Figure 1. (a) Cultural pictures of fungal isolates from refinery effluent. Keys: (a)=Surface characteristics; (b) = reverse characteristics. (b) Cultural pictures of fungal isolates from refinery effluent. Keys: (a) = Surface characteristics; (b) = reverse characteristics.

to F23) in terms of colour, surface characteristics, reverse, edge and diameter. Pictorial representations of the surface and reverse characteristics of the fungal isolates are shown in Fig. 1(a) and (b).

The microscopic features of the isolates are presented in Fig. 2(a) and (b) showing the conidia, spores and conidiophores. Aspergillus species had septate hyphae, hyaline conidiophores and radial conidial head bearing 
a
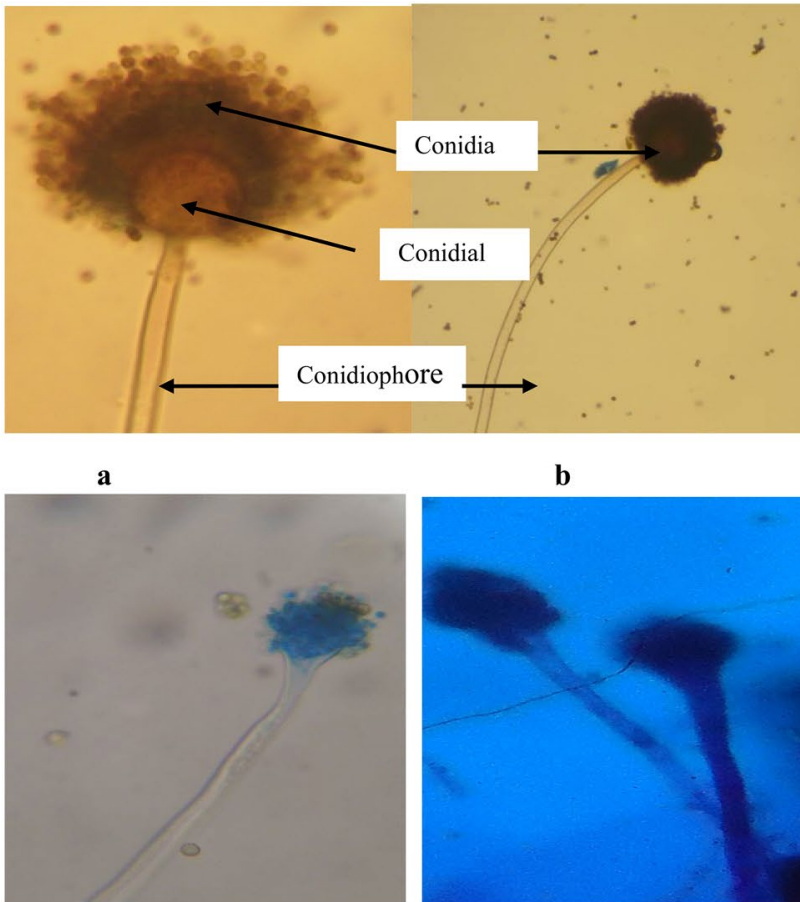

e

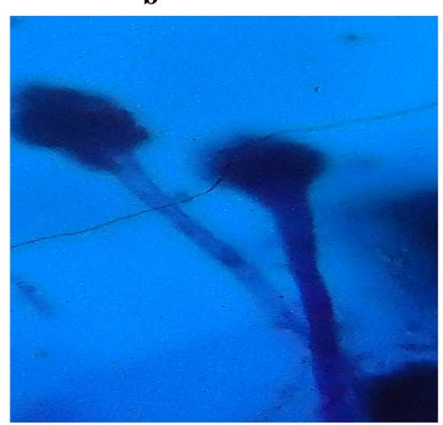

f

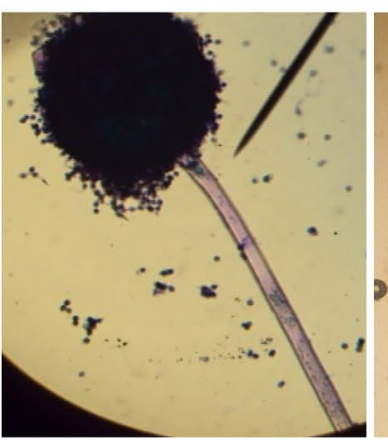

c

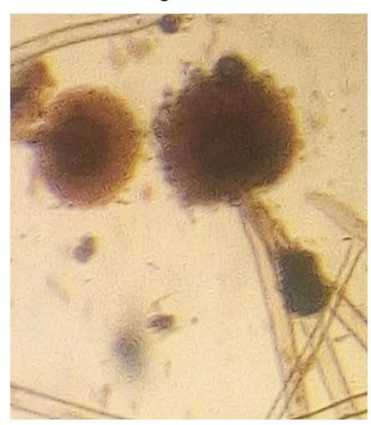

g

b

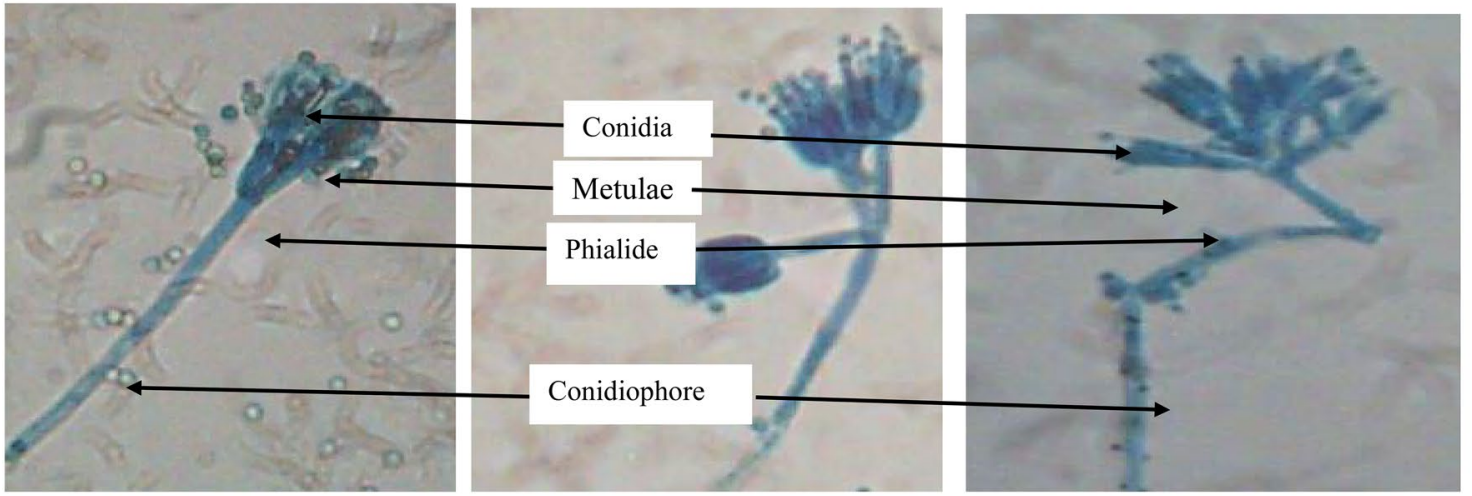

1

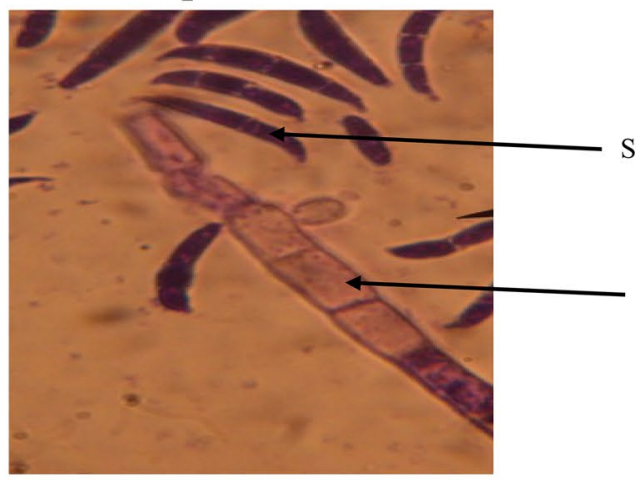

4
2

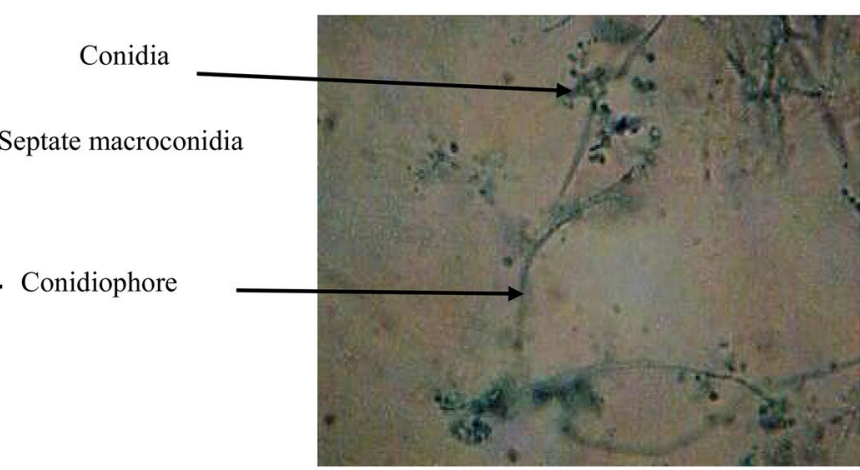

5

Keys : $\mathbf{1}=$ Penicillium citrinum; $\mathbf{2}=$ Penicillium shearii; $\mathbf{3}=$ Penicillium simplicissimum $; \mathbf{4}=$ Fusarium incarnatum; $5=$ Trichoderma erinaceum

Figure 2. (a) Microscopic features of Aspergillus species (×40 magnification). (b) Microscopic features of Penicillium, Fusarium and Trichoderma species ( $\times 40$ magnification). 


\begin{tabular}{|c|c|c|c|c|c|c|c|c|c|}
\hline \multirow[b]{2}{*}{ Fungi } & \multirow[b]{2}{*}{ Isolate } & \multicolumn{2}{|l|}{ ITS } & \multicolumn{2}{|l|}{ Beta-tubulin } & \multicolumn{2}{|c|}{ Calmodulin } & \multicolumn{2}{|l|}{ RPB2 } \\
\hline & & Identity (\%) & $\begin{array}{l}\text { Accession } \\
\text { No. }\end{array}$ & Identity (\%) & $\begin{array}{l}\text { Accession } \\
\text { No. }\end{array}$ & Identity (\%) & $\begin{array}{l}\text { Accession } \\
\text { No. }\end{array}$ & Identity (\%) & $\begin{array}{l}\text { Accession } \\
\text { No. }\end{array}$ \\
\hline $\begin{array}{l}\text { Aspergillus } \\
\text { flavus }\end{array}$ & $\mathrm{F} 1$ & 96.89 & MK828704 & 100 & MH180047 & - & - & - & - \\
\hline A. flavus & F1D & - & - & 100 & MG517775 & - & - & - & - \\
\hline A. japonicus & F2 & 99.11 & MK840963 & 100 & MH208743 & - & - & - & - \\
\hline A. japonicus & F2D & 97.53 & MK840964 & - & - & - & - & - & - \\
\hline A. niger & F3 & 100 & MK828713 & 99.79 & HQ632731 & - & - & - & - \\
\hline A. niger & F3D & - & - & 100 & MH781323 & - & - & - & - \\
\hline A. niger & F5 & 98.99 & MK840965 & 100 & MH781323 & 98.48 & JX500080 & - & - \\
\hline A. niger & F5D & 97.75 & MK840966 & 99.59 & LC389053 & 98.87 & MG991517 & - & - \\
\hline A. melleus & F6 & 96.71 & MK840967 & - & - & - & - & - & - \\
\hline A. sydowii & F7 & 98.95 & MK828705 & 100 & MH426599 & 96.86 & LN898812 & - & - \\
\hline A. sydowii & F7D & 99.45 & MK828710 & 100 & MH644075 & 96.63 & LN898808 & - & - \\
\hline $\begin{array}{l}\text { Fusariumin- } \\
\text { carnatum }\end{array}$ & F8 & - & - & 98.83 & KT374271 & - & - & - & - \\
\hline $\begin{array}{l}\text { F. incarna- } \\
\text { tum }\end{array}$ & F8D & - & - & 98.90 & KJ020856 & - & - & - & - \\
\hline A. niger & F10 & 99.41 & MK828708 & 100 & MH781319 & - & - & - & - \\
\hline A. niger & F10D & - & - & 100 & MH208814 & - & - & - & - \\
\hline A. fumigatus & F11 & 99.27 & MK816855 & - & - & - & - & - & - \\
\hline $\begin{array}{l}\text { Penicillium- } \\
\text { shearii }\end{array}$ & F12 & 98.96 & MK840968 & - & - & - & - & - & - \\
\hline P. shearii & F12D & 95.83 & MK828709 & - & - & - & - & - & - \\
\hline T. erinaceum & F13 & 98.53 & MK840969 & - & - & - & - & - & - \\
\hline $\begin{array}{l}\text { A. quadrilin- } \\
\text { eatus }\end{array}$ & F14 & 97.98 & MK840970 & - & - & - & - & - & - \\
\hline A. fumigatus & F16 & - & - & 100 & MH781343 & - & - & - & - \\
\hline A. fumigatus & F16D & - & - & 100 & MH781334 & - & - & - & - \\
\hline A. sydowii & F18 & 99.41 & MK828707 & 100 & LC367596 & - & - & - & - \\
\hline A. sydowii & F18D & 97.34 & MK828706 & 97.34 & MK828706 & - & - & - & - \\
\hline P. citrinum & F19 & 99.27 & MK828711 & 99.63 & MG991339 & - & - & 99.27 & MK828711 \\
\hline P. citrinum & F19D & 99.54 & MK840969 & - & - & - & - & 99.27 & MK828711 \\
\hline $\begin{array}{l}\text { P. simplicis- } \\
\text { simum }\end{array}$ & F23 & 98.93 & MK840973 & 99.02 & GU981631 & - & - & - & - \\
\hline $\begin{array}{l}\text { P. simplicis- } \\
\text { simum }\end{array}$ & F23D & 99.27 & MK828712 & 99.32 & GU981632 & - & - & - & - \\
\hline
\end{tabular}

Table 3. Accession numbers of amplified nucleotide sequences from fungal. Isolates. “-” denotes no clear PCR products were obtained using primers from Table 1.

the spores (Fig. 2a). Penicillium species appeared as septate hyphae with conidiophores and secondary branches (metulae). The metulae bear flasked shaped phialides with unbranched chains of round conidia (Fig. 2b). Fusarium species showed septate hyphae, multiseptate canoe shaped macroconidia attached to the conidiophores (Fig. 2b). Trichoderma species appeared as septate hyphae, short conidiophores which are flask shaped clustering together at the end of each phialides (Fig. 2b).

The genus Aspergillus is one of the most well researched fungi genera with over 200 officially recognized species $^{35}$. The ubiquitous nature of Aspergillus may be due to their saprophytic feeding habit as well as their ability to grow in a wide range of environment ${ }^{25}$. This observation sturdily indicates that members of these fungal genera isolated, have the capacity to survive and withstand toxic effects of polycyclic aromatic hydrocarbons ${ }^{26}$.

Polymerase Chain Reaction (PCR) of fungal isolates obtained. PCR amplification of internal transcribed spacer (ITS), beta tubulin gene (Ben A), calmodulin gene (CMD) and RNA Polymerase II Second Largest Subunit (RPB2) genes of the fungal isolates are discussed below.

Amplification of internal transcribed spacer. Thirteen out of the fifteen fungal isolates were positive to PCR amplification of ITS regions, with amplicon sizes of 600 base pairs. Although, the ITS region is widely used as universal primers for fungi, it is not sufficient for identifying most fungi to specie level due to their low variability and slow evolution ${ }^{17,36}$. Visagie et al. ${ }^{18}$ however suggested the use of other molecular markers for accurate identification of fungal species and phylogenetic relationships. Other secondary identification markers for Aspergillus and Penicillium species (and other ascomycetes) used in this study were beta tubulin; calmodulin and RPB2. These protein-encoding genes contained highly variable intron regions $\mathbf{s}^{14,19,37}$. 


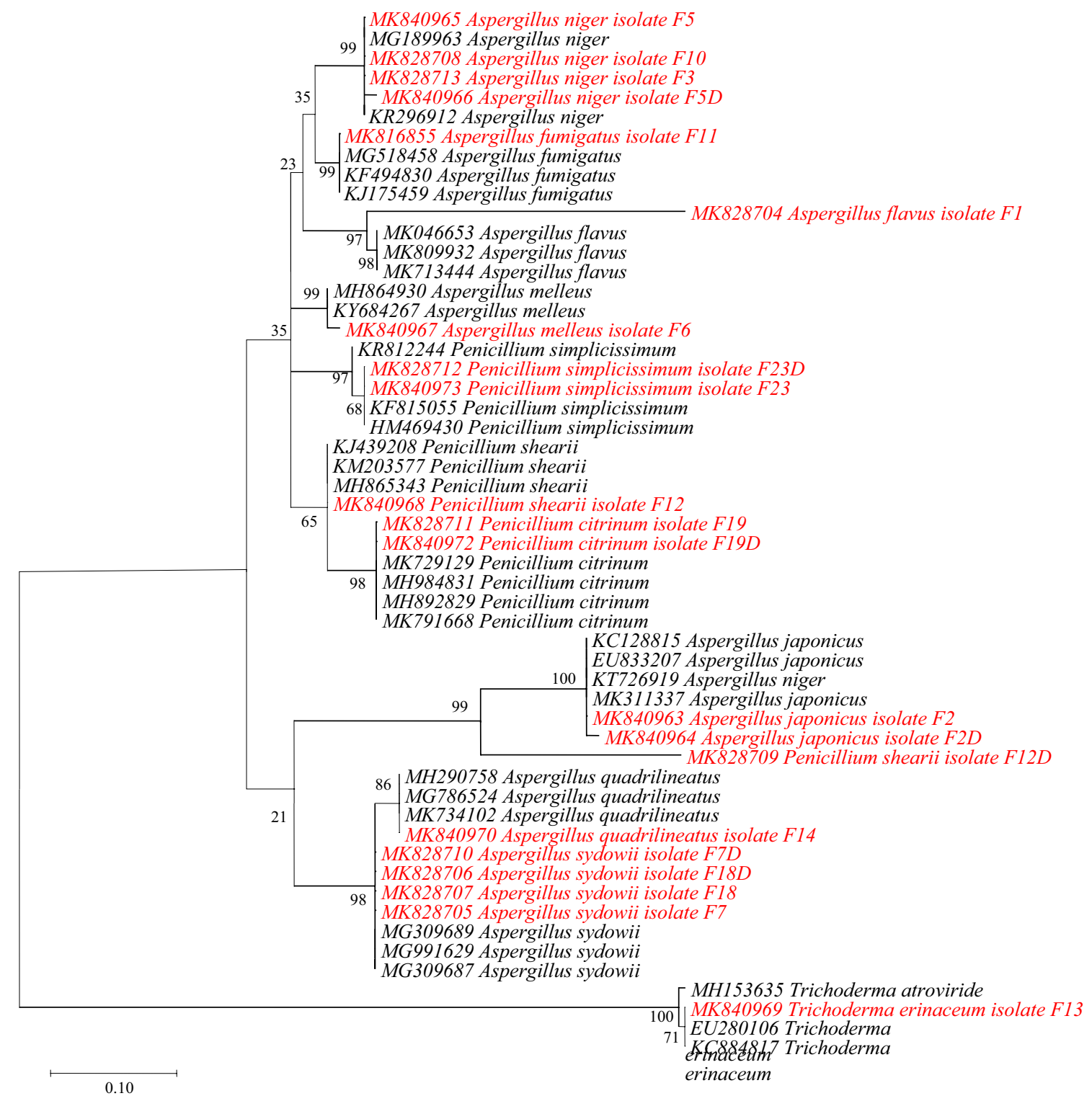

Figure 3. Phylogenetic tree of partial ITS gene sequences by maximum likelihood. Note: Sequences from this study are shown in red.

Amplification of beta-tubulin gene. Thirteen isolates (13) out of the fifteen (15) isolates were positive with amplicon sizes of 480-600 bp. This results were similar to those obtained in previous studies ${ }^{38-40}$. Eulalia et al. ${ }^{39}$ and Kamarudin and Zakaria ${ }^{40}$ amplified Aspergillus fragments of beta tubulin genes with amplicon sizes in the range of 550 to $600 \mathrm{bp}$. Samson et al. ${ }^{41}$ and Erika et al..$^{42}$, obtained beta tubulin gene amplicon sizes of ranging from 432 to $550 \mathrm{bp}$ for Aspergillus, Penicillium and other fungal species. Beta-tubulin genes are found in all eukaryotes and have been used for phylogenetic analysis in fungi from kingdom to the species level. Reports have shown that beta tubulin genes have more variability compared to the ITS region ${ }^{18}$. This amount of variation is suitable for determining phylogenetic relationship of closely related species of Penicillium and Aspergillus genera ${ }^{19}$.

Amplification of RPB2 gene. The amplified partial RPB2 genes of the isolates revealed that only two isolates, $P$. citrinum (F19) and P. citrinum (F19D) were positive with amplicon sizes of approximately 650 and 600 base pairs respectively. This result is in agreement with the studies of Houbraken \& Samson ${ }^{17}$ who identified Penicillium citrinum using RPB2 genes.

Amplification of Calmodulin gene. The result of the amplified calmodulin genes of the isolates showed that $A$. niger (F5), A. niger (F10) and P. citrinum (F19) had sizes of $500 \mathrm{bp}, 550 \mathrm{bp}$ and $500 \mathrm{bp}$ respectively. Calmodulin gene has been considered important for the identification of Aspergillus species, and some reports have even stated it should be used as the primary gene for identification of Aspergillus species ${ }^{38,41}$. 


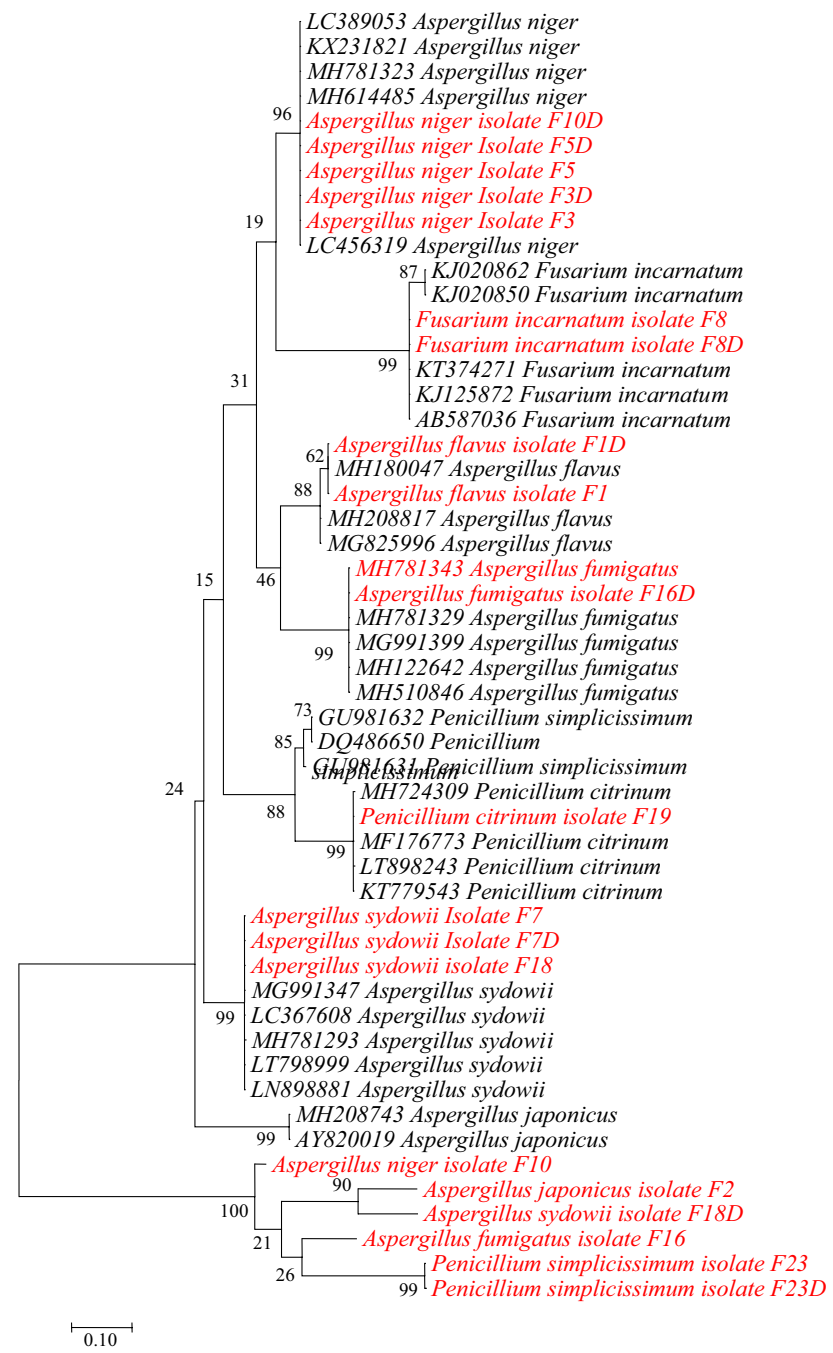

Figure 4. Phylogenetic tree of partial $\beta$-tubulin gene sequences by maximum likelihood. Note: Sequences from this study are shown in red.

Gene Sequences of Fungal Isolates. Identifications based on cultural features were confirmed by sequence analysis of the isolates. Basic Logical Alignment Search Tool (BLAST) results of ITS region, Beta-tubulin, RPB2 gene and calmodulin gene sequences of this study in National Center for Biotechnology Information (NCBI) provided relationships and similarities with reference sequences in GenBank. The amplified sequences of each gene were submitted to GenBank and their accession numbers were assigned (Table 3). The results in Table 3 revealed that most isolates had above $96 \%$ similar identity to reference sequences of GenBank.

There has been little or no extensive research on identification of the Fungiusing different molecular marker approach in Nigeria. Focus has been on macroscopic and microscopic features.

Phylogenetic Tree. Phylogenetic trees of the fungal isolates revealed that the isolates were clustered in grouping patterns of close resemblance. Sequences from this study are shown in red colours while sequences from GenBank are shown in black. Test of phylogeny was bootstrap of 1000 replications. Phylogenetic tree based on ITS gene revealed that the alignment matrix contained 54 nucleotide sequences with 209 positions in the final dataset. All isolates of Aspergillus and Penicillium species were clustered had cluster identity of above $95 \%$ with those from GenBank. The tree was out grouped by T. erinaceum (Fig. 3).

Beta-tubulin gene alignment matrix contained 52 nucleotide sequences with 19 positions in the final dataset. All the fungal species had above $85 \%$ cluster similarity with fungal species from GenBank while P. Simplicissimum was placed in the out group (Fig. 4).

Phylogenetic tree based on partial RPB2 gene revealed that the alignment matrix involved 19 nucleotide sequences with a total of 404 positions in the final dataset. The two positive isolates of Penicillium citrinum shared $90 \%$ cluster similarities with sequences from GenBank (Fig. 5). 


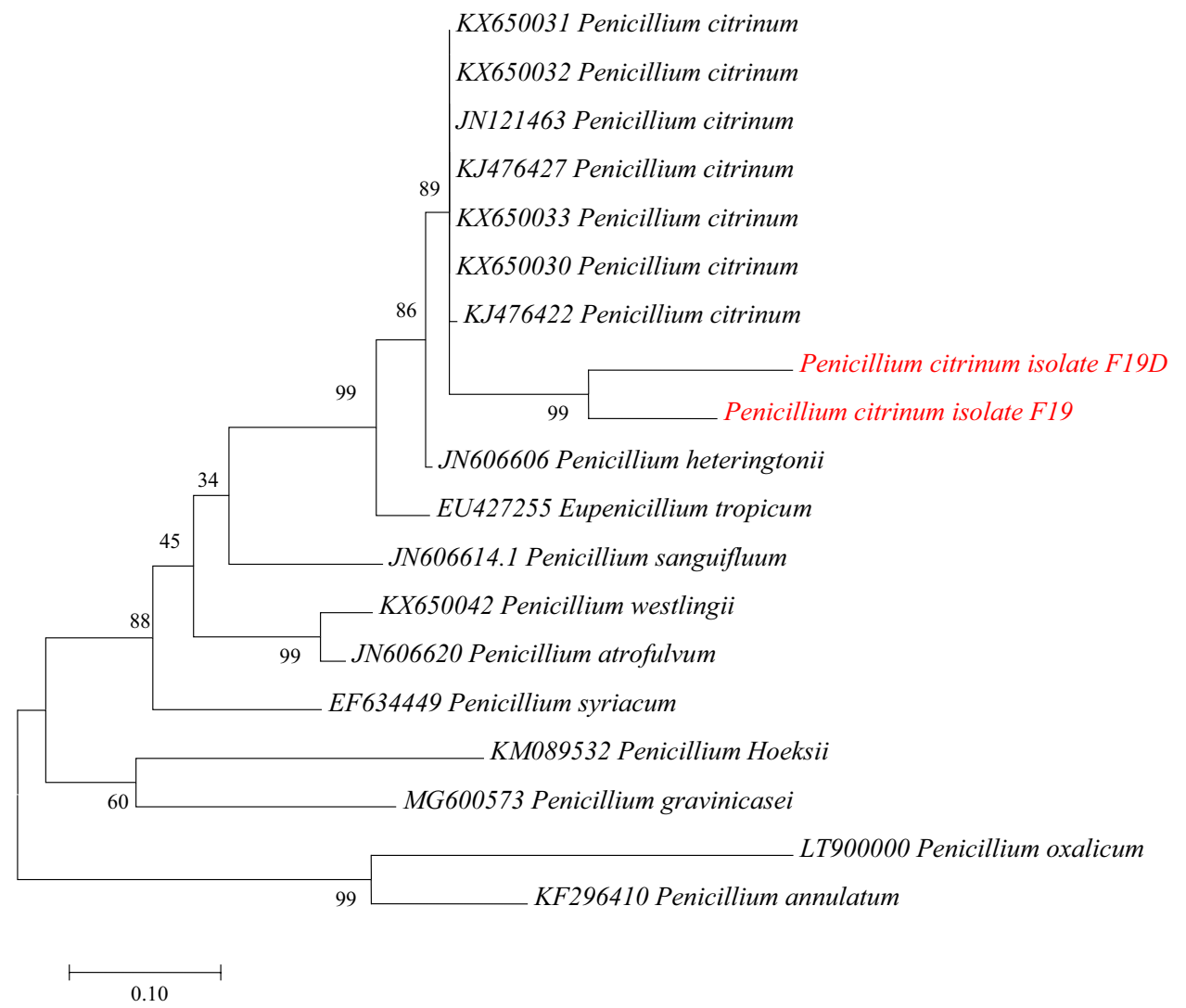

Figure 5. Phylogenetic tree of partial RPB2 gene sequences by maximum likelihood. Note: Sequences from this study are shown in red.

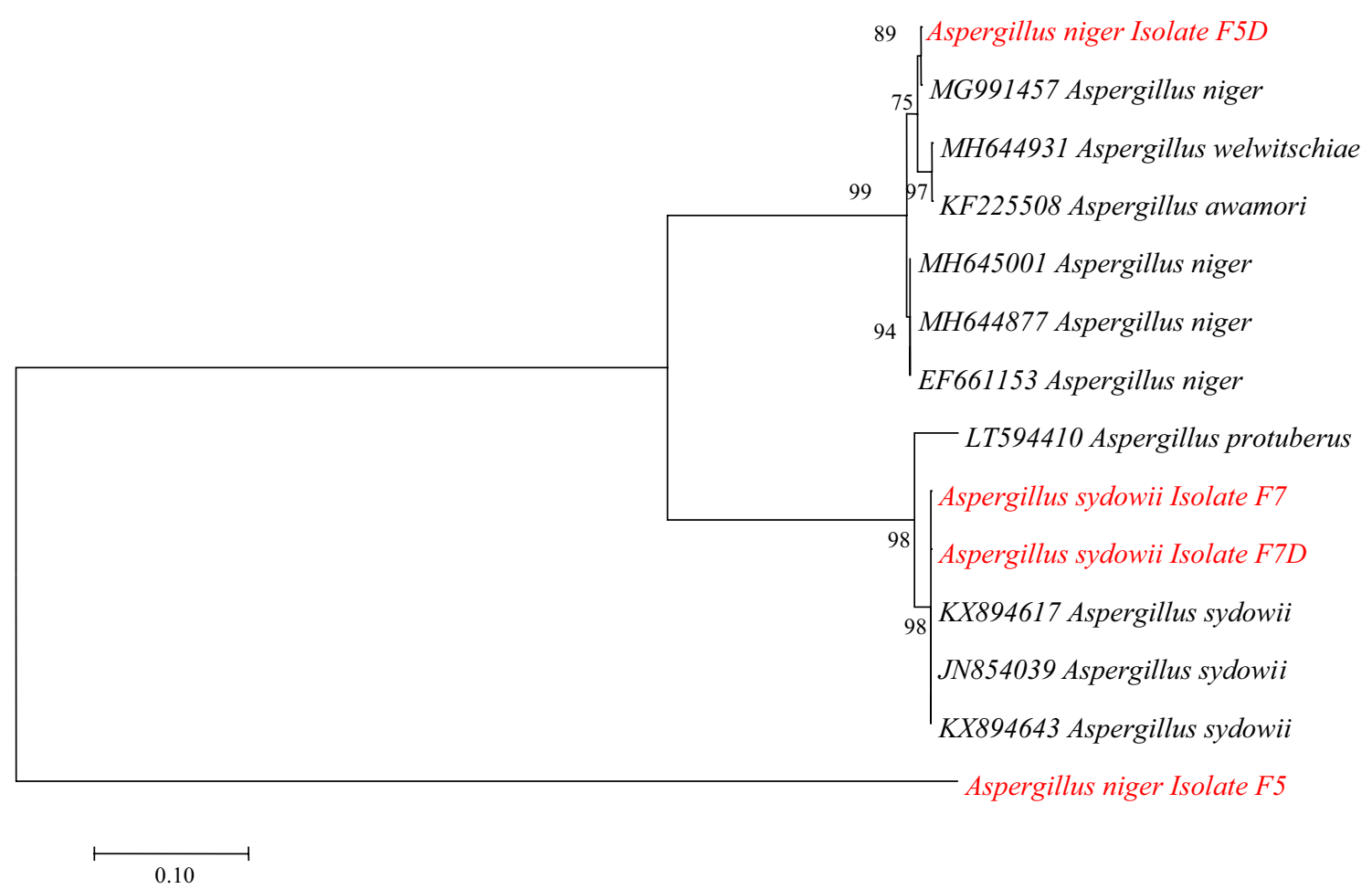

Figure 6. Phylogenetic tree of calmodulin gene sequences by maximum likelihood. 
Phylogenetic tree based on calmodulin gene had an alignment matrix of 14 sequences. A. niger (F5D) shared $89 \%$ cluster similarity while the two isolates of $A$. sydowii (F7 and F7D) had equal (98\%) cluster similarities with sequences from GenBank. A. niger (F5) falls in the outgroup (Fig. 6).

The phylogenetic trees revealed that related species are clustered together which indicates a clear and well resolved classification and evolutionary history of the isolates ${ }^{19,37,40}$.

\section{Conclusion}

There has been little or no extensive research on identification of the Fungi using different molecular marker approach in Nigeria. Focus has been on cultural and microscopic features. The fungal isolates from this study were further subjected to PCR amplification coupled with DNA sequencing of four molecular genes markers. The fungal species isolated from untreated refinery effluent consist of the following genera; Aspergillus, Penicillium, Fusarium, and Trichoderma with Aspergillus being the predominant genus. Sequence results obtained revealed above $95 \%$ similarities between the isolates in this study and those found in GenBank. The identification and molecular characterization of the fungal isolates to specie level gave a better result by PCR amplification and sequencing of ITS region, partial beta tubulin, calmodulin and RPB2 genes. Therefore should be used as molecular markers for species level identification of fungi (especially Aspergillus and Penicillium as proved in this study).

Received: 2 March 2021; Accepted: 10 January 2022

Published online: 08 February 2022

\section{References}

1. Ramganesh, S., Timothy, S., Sudharshan, S. \& Willem, A. J. N. Industrial effluents harbor a unique diversity of fungal community structures as revealed by high-throughput sequencing analysis. Pol. J. Environ. Stud. 28(4), 2353-2362. https://doi.org/10.15244/ pjoes/90791 (2019).

2. Hailemariam, A. A. et al. Diversity, co-occurrence and implications of fungal communities in wastewater treatment plants. Sci. Rep. 9, 14056. https://doi.org/10.1038/s41598-019-50624-z (2019).

3. Maza-Márquez, P., Lee, M. D. \& Bebout, B. M. The abundance and diversity of fungi in a hypersaline microbial mat from Guerrero Negro, Baja California, México. J. Fungi 7, 210. https://doi.org/10.3390/jof7030210 (2021).

4. Ma, X., Baron, J. L., Vikram, A., Stout, J. E. \& Bibby, K. Fungal diversity and presence of potentially pathogenic fungi in a hospital hot water system treated with on-site monochloramine. Water Res. 71, 197-206 (2015).

5. Wei, Z. et al. The divergence between fungal and bacterial communities in seasonal and spatial variations of wastewater treatment plants. Sci. Total Environ. 628, 969-978 (2018).

6. Ekowati, Y. et al. Clinically relevant fungi in water and on surfaces in an indoor swimming pool facility. Int. J. Hyg. Environ. Health. 220, 1152-1160 (2017).

7. Manoharachary, C., Kunwar, I. K. \& Reddy, S. V. Biodiversity, phylogeny and evolution of fungi. In Nature at Work: Ongoing Saga of Evolution (ed. Sharma, V. P.) (Springer, New Delhi, 2010). https://doi.org/10.1007/978-81-8489-992-4_10.

8. Raja, H. A., Miller, A. N., Pearce, C. J. \& Oberlies, N. H. Fungal identification using molecular tools: A primer for the natural products research community. J. Nat. Prod. 80, 756-770. https://doi.org/10.1021/acs.jnatprod.6b01085 (2017).

9. Liu, J., Li, J., Tao, Y., Sellamuthu, B. \& Walsh, R. Analysis of bacterial, fungal and archaeal populations from a municipal wastewater treatment plant developing an innovative aerobic granular sludge process. World J. Microbiol. Biotechnol. 33, 14 (2017).

10. Simeos, M. F. et al. Soil and rhizosphere associated fungi in gray Mangroves (Avicennia marina) from the Red Sea-A metagenomic approach. Genom. Proteom. Bioinform. 13, 310-320. https://doi.org/10.1016/j.gpb.2015.07.002 (2015).

11. Helal, G. A., Mostafa, M. H. \& El-Said, M. A. Fungi in the sewage-treatment Zeinein plant, Cairo, Egypt. J. Basic Appl. Mycol. 2(2011), 69-82 (2011).

12. Mishra, S. \& Mishra, A. To study the diversity of fungal species in sewage water of Durg district. IOSR J. Environ. Sci. Toxicol. Food Technol. 1(6), 45-49 (2015).

13. Das, S., Dash, H. R., Mangwani, N., Chakraborty, J. \& Kumari, S. Understanding molecular identification and polyphasic taxonomic approaches for genetic relatedness and phylogenetic relationships of microorganisms. J. Microbiol. Methods 103, 80-100. https:// doi.org/10.1016/j.mimet.2014.05.013 (2014).

14. Yin, G., Zhang, Y., Pennerman, K. K., Wu, G. \& Hua, S. S. T. Characterization of Blue Mold Penicillium Species isolated from stored fruits using multiple highly conserved loci. J. Fungi. 3, 1-10. https://doi.org/10.3390/jof3010012 (2017).

15. Rajeshkumar, K. C., Yilmaz, N. \& Marathe, S. D. Morphology and multigene phylogeny of Talaromyces amyrossmaniae, a new synnematous species belonging to the section Trachyspermi from India. Mycokeys 45, 41-56. https://doi.org/10.3897/mycokeys. 45.32549 (2019).

16. Adeniyi, M. et al. Molecular identification of some wild Nigerian mushrooms using internal transcribed spacer: Polymerase chain reaction. AMB Express 8, 1-9. https://doi.org/10.1186/s13568-018-0661-9 (2018).

17. Houbraken, J. \& Samson, R. A. Phylogeny of Penicillium and the segregation of Trichocomaceae into three families. Stud. Mycol. 70, 1-51. https://doi.org/10.3114/sim.2011.70.01 (2011).

18. Visagie, C. M. et al. Studies in mycology. Stud. Mycol. 78, 343-371. https://doi.org/10.1016/j.simyco.2014.09.001 (2014).

19. Asan, A., Kolanlarli, T. K., Sen, B. \& Okten, S. Biodiversity of Penicillium species isolated from Edirne Söğütlük Forest soil (Turkey ). Nisan 10, 26-39 (2019).

20. De Carvalho, M. J. A. et al. Functional and genetic characterization of calmodulin from the dimorphic and pathogenic fungus Paracoccidioides brasiliensis. Fungal Genet. Biol. 39, 204-210. https://doi.org/10.1016/S1087-1845(03)00044-6 (2003).

21. De Cassia Garcia Simao, R. \& Gomes, S. L. Structure, expression, and functional analysis of the gene coding for calmodulin in the chytridiomycete Blastocladiella emersonii. J. Bacteriol. 183, 2280-2288. https://doi.org/10.1128/JB.183.7.2280-2288.2001 (2001).

22. Gerber, A., Ito, K., Chu, C. N. \& Roeder, R. G. Induced RPB1 depletion reveals a direct gene-specific control of RNA Polymerase III function by RNA Polymerase II. Mol. Cell 78, 765-778. https://doi.org/10.1016/j.molcel.2020.03.023 (2020).

23. Malkus, A. et al. RNA polymerase II gene (RPB2) encoding the second largest protein subunit in Phaeosphaeria nodorum and $P$. avenaria. Mycol. Res. 110, 1152-1164 (2006).

24. Vetrovsky, T., Kolarik, M., Zifcakova, L., Zelenka, T. \& Baldrian, P. The rpb2 gene represents a viable alternative molecular marker for the analysis of environmental fungal communities. Mol. Ecol. Resour. 16, 388-401. https://doi.org/10.1111/1755-0998.12456 (2015).

25. Machido, D. A., Ezeonuegbu, B. A. \& Yakubu, S. E. Resistance to some heavy metals among fungal flora of raw refinery effluent. J. Appl. Sci. Environ. Manag. 18, 623-627. https://doi.org/10.4314/jasem.v18i4.10 (2014).

26. Ezeonuegbu, B. A., Machido, D. A. \& Yakubu, S. E. Resistance of some heavy metals among fungal flora of raw refinery effluent. J. Appl. Sci. Environ. Manag. 18, 623-627 (2014). 
27. Barnett, H. L. \& Hunter, B. B. Illustrated Genera of Imperfect Fungi 4th edn. (Prentice Hall, 1999).

28. Hakeem, A. S. \& Bhatnagar, B. Heavy metal reduction of pulp and paper mill effluent by indigenous microbes. Asian J. Exp. Biol. Sci. 1, 203-210 (2010).

29. Viegas, C., Sabino, R., Botelho, D., Santos, M. \& Gomes, A. Q. Assessment of exposure to Penicillium glabrum complex in cork industry using complementing methods. Arch. Ind. Hyg. Toxicol. 66, 203-207. https://doi.org/10.1515/aiht-2015-66-2614 (2015).

30. Khandavilli, R., Meena, R. \& Bd, S. Fungal phylogenetic diversity in estuarine sediments of Gautami. Curr. Res. Environ. Appl. Mycol. 6, 268-276. https://doi.org/10.5943/cream/6/4/4 (2016).

31. Houbraken, J., Frisvad, J. C. \& Samson, R. A. Sex in penicillium series roqueforti. IMA Fungus 1, 171-180 (2010).

32. Goujon, M. et al. A new bioinformatics analysis tools framework at EMBL_EBI. Nucleic Acids Res. 38, W695-W699 (2010).

33. Kumar, S., Stecher, G. \& Tamura, K. MEGA 7: Molecular evolutionary genetics analysis version 7.0 for bigger datasets. Mol. Biol. Evol. 33, 1870 (2015).

34. Sidiq, F., Hoostal, M. \& Rogers, S. O. Rapid identification of fungi in culture - negative clinical blood and respiratory samples by DNA sequence analyses. BMC. Res. Notes 9, 1-8. https://doi.org/10.1186/s13104-016-2097-0 (2016).

35. Oyebanji, E. O., Adekunle, A. A., Coker, H. A. B. \& Adebami, G. E. Mycotic loads' determination of non-sterile pharmaceuticals in lagos state and $16 \mathrm{~s}$ rdna identification of the fungal isolates. J. Appl. Pharm. Res. 6, 16-28. https://doi.org/10.18231/2348-0335. 2018.0007 (2018).

36. Tiwari, P., Kumar, B., Kaur, G. \& Kaur, H. Phytochemical screening and extraction: A review. Int. Pharm. Sci. 1, 98-106 (2011).

37. Ozdil, S., Asan, A., Sen, B. \& Okten, S. Biodiversity of Airborne Fungi in the Indoor Environment of Refrigerators Used in Houses. J. Fungus. 8, 109-124. https://doi.org/10.15318/fungus.2017.41 (2017).

38. Ashtiani, N. M., Kachuei, R., Yalfani, R. \& Harchegani, A. B. Identification of Aspergillus sections Flavi, Nigri, and Fumigati and their differentiation using specific primers. Infez. Med. 2, 127-132 (2017).

39. Eulalia, M. M., Agnieszka, F. \& Zalewska, E. D. Aspergillus penicillioides Speg. Implicated in Keratomycosis. Pol. J. Microbiol. 67, 407-416 (2018).

40. Kamarudin, N. A. \& Zakaria, L. Characterization of two xerophilic Aspergillus spp. from peanuts (Arachis hypogaea) Nur. Malays. J. Microbiol. 14, 41-48 (2018).

41. Samson, R. A. et al. Phylogeny, identification and nomenclature of the genus Aspergillus. Stud. Mycol. 78, 141-173. https://doi. org/10.1016/j.simyco.2014.07.004 (2014).

42. Wolski, E. A., Barrera, V., Castellari, C. \& Gonzalez, J. F. Biodegradation of phenol in static cultures by Penicillium chrysogenum EK1: catalytic abilities and residual photo toxicity. Rev. Argent. Microbiol. 44, 113-121 (2012).

\section{Acknowledgements}

The authors would like to extend their gratitude to King Saud University (Riyadh, Saudi Arabia) for supporting of this research through Researchers Supporting Project number (RSP-2021/403) and appreciation to Human Science Research Centre - University of Derby, UK. The authors also wish to express their profound gratitude to management of African Bioscience Limited and International Institute of Tropical Agriculture (IITA) Ibadan, Nigeria for their guidance and contributions in conducting the molecular research.

\section{Author contributions}

Conceptualization, B.A.E., M.D.A., W.C.M.Z. and J.W.S.; methodology, B.A.E., M.D.A., W.C.M.Z. and J.W.S.; formal analysis, B.A.E., M.D.A., W.C.M.Z., J.W.S. and C.A.Y.; investigation, B.A.E., M.D.A., W.C.M.Z. and J.W.S.; writing original draft, B.A.E., M.D.A., W.C.M.Z. and J.W.S.; resources, review and editing, B.A.E., M.D.A., W.C.M.Z., J.W.S., H.F.H., M.H.M., C.A.Y., G.M-H., G.D.Z. and G.E.-S.B.; supervision, M.D.A., W.C.M.Z. and J.W.S.; project administration, B.A.E., M.D.A., W.C.M.Z., G.M.-H. and G.D.Z.

\section{Competing interests}

The authors declare no competing interests.

\section{Additional information}

Correspondence and requests for materials should be addressed to B.A.E. or G.D.Z.

Reprints and permissions information is available at www.nature.com/reprints.

Publisher's note Springer Nature remains neutral with regard to jurisdictional claims in published maps and institutional affiliations.

(c) (i) Open Access This article is licensed under a Creative Commons Attribution 4.0 International License, which permits use, sharing, adaptation, distribution and reproduction in any medium or format, as long as you give appropriate credit to the original author(s) and the source, provide a link to the Creative Commons licence, and indicate if changes were made. The images or other third party material in this article are included in the article's Creative Commons licence, unless indicated otherwise in a credit line to the material. If material is not included in the article's Creative Commons licence and your intended use is not permitted by statutory regulation or exceeds the permitted use, you will need to obtain permission directly from the copyright holder. To view a copy of this licence, visit http://creativecommons.org/licenses/by/4.0/.

(c) The Author(s) 2022 